Advocacy coalitions, beliefs and climate change policy in the United States

Kukkonen, Anna Kristiina

2017-05-03

Kukkonen , A K , Ylä-Anttila, M T \& Broadbent , J 2017 , ' Advocacy coalitions, beliefs and climate change policy in the United States ', Public Administration, vol. 95 , no. 3 , pp. pÿ713 729 . https://doi.org/10.1111/padm.12321

http://hdl.handle.net/10138/311257

https://doi.org/10.1111/padm.12321

unspecified

acceptedVersion

Downloaded from Helda, University of Helsinki institutional repository.

This is an electronic reprint of the original article.

This reprint may differ from the original in pagination and typographic detail.

Please cite the original version. 


\section{Advocacy Coalitions, Beliefs and Climate Change Policy in}

\section{the United States}

The Advocacy Coalition Framework (ACF) asserts that disagreement over policy core beliefs divides organizations into competing coalitions. We apply Discourse Network Analysis to 1410 statements in Wall Street Journal, New York Times and USA Today, to investigate what kinds of beliefs contribute to coalition formation in the climate policy debate in the United States. We find that the beliefs concerning the reality of anthropogenic climate change, the importance of ecology over economy and desirability of governmental regulation divide organizations into three coalitions: the economy, ecology and science coalitions. Policy preferences such as cap and trade do not; they find support across coalition lines. Based on these findings, we suggest ACF theory could be clarified to better account for how beliefs concerning policy instruments contribute to coalition formation. In some policy domains, policy instruments are where opposing coalitions find agreement. In others, they are more divisive.

Keywords: climate change; global warming; climate politics; news media; discourse network analysis; Advocacy Coalition Framework

\section{Introduction}

The Advocacy Coalition Framework (Sabatier 1988; Sabatier \& Jenkins-Smith 1993) is one of the most prominent theoretical frameworks for examining the features of policy process and change. The ACF asserts that 
organizations group into competing advocacy coalitions on the basis of shared policy beliefs and that the coalitions have a crucial role in influencing policy outcomes. The ACF's strength comes from its broad view of politics as it focuses on the relationships between various organizations who aim to influence the normative orientations and outcomes of a specific policy subsystem (Sabatier \& Jenkins-Smith 1999; Jenkins-Smith et al. 2014).

According to the ACF, the most important factor tying advocacy coalitions together is shared policy core beliefs (Sabatier \& Weible 1993; Sabatier 1998, p. 103). Policy core beliefs are generally defined as including "basic orientation and value priorities for the policy systems, or whose welfare in the policy system is of utmost concern", as well as "assessments of the seriousness of the problem, its basic causes and the preferred solutions for addressing it" (JenkinsSmith et al. 2014, p. 191). Policy core beliefs are contrasted with deep core beliefs that are too general to form as a basis for coalition formation, and with secondary beliefs, that are too specific to play this role. However, assessing three decades of scholarship on the ACF, the creators of the framework have identified considerable "variation in conceptualizations and measurement of belief systems", and called for an "effort to clarify the theoretical distinction between policy core and secondary aspects" (Jenkins-Smith et al. 2014, p. 196).

In this paper, we heed this call through empirically analyzing coalition formation in the media debate on climate change in the United States. We separately test the influence of different types of beliefs on coalition formation. We find that the empirical and normative beliefs, such as those concerning the validity of climate science and prioritization of ecological over economic objectives do contribute to coalition formation, while beliefs concerning policy instruments, such as cap and 
trade, do not. Comparing these results with those of earlier studies, we suggest ACF theory could be refined to better account for the role of beliefs concerning policy instruments in coalition formation. In some policy domains and moments in time, such as the one studied here, policy instruments are where opposing coalitions find agreement. In others, they are more divisive.

Our main contribution, thus, is theoretical: clarifying the role of different types of beliefs in coalition formation. For this reason, our data is from an exceptional time period in the history of US climate change policymaking. We analyze the years 2007-2008, during which climate change was a more salient issue in the US public debate than ever before or after: climate change legislation was making progress in an unprecedented way at the federal and state levels (KnoxHayes 2012). This time period, during which old disagreements dividing coalitions remained but some consensus was also forming, provides the best data for our task, which is to investigate what kind of beliefs divide organizations into opposing coalitions and what kinds find support across coalition lines. Our intention, therefore, is not to provide an overall picture of the climate change debate in the US, nor to analyze coalition formation in this policy domain more generally - both of these tasks have already been taken up in earlier studies (e.g. Fisher et al. 2012; KnoxHayes 2012; Dunlap \& McCright 2015; Farrell 2015). Our results should be read with this in mind.

The overall picture of US climate politics painted by earlier studies is one of policy stagnation. No government has been able to pass federal climate laws, and the task has been delegated to subnational efforts instead (Rabe 2009). Studies have particularly underlined the strategies of the climate change counter movement which includes influential organizations with links to the fossil fuel industry. These 
organizations have actively mobilized in various forums to advocate scientific uncertainty and economic threat scenarios in order to shape public perceptions of climate change (McCright \& Dunlap 2003, 2000; Pooley 2010; Oreskes \& Conway 2010; Greenberg et al. 2011, Hoffman 2011; Farrell 2016, 2015; Boussalis \& Coan 2016). The counter movement's strategies seem to be working. Public opinion on climate change has become increasingly polarized along ideological lines (McCright \& Dunlap 2011; Brulle et al. 2012), and a majority of Americans still cast doubt on anthropogenic global warming (Leiserowitz et al. 2015).

Around the years 2007-8 however, the positions presented at congressional hearings on climate change became more consensual across partisan lines, especially concerning the policy instrument of cap and trade (Fisher et al. 2013). This increase in consensus almost resulted in policy change when the American Clean Air and Security Act aimed at establishing a federal cap and trade policy, went all the way through the House of Representatives before hitting a wall in the Senate (Rabe 2010). Since then, the counter-movement has regrouped and polarization of beliefs concerning climate change has continued (Dunlap \& McCright 2015)

The remainder of this paper is organized as follows: first, we present the current state of the theoretical debate on the role of beliefs in coalition formation in the ACF and our research questions. Second, we present our newspaper data and the method of Discourse Network Analysis. Third, we show that the policy subsystem - as presented in the media - is divided in three coalitions, the Economy Coalition, the Ecology Coalition and the Science Coalition, based on their diverging policy core beliefs, and look at the composition of the coalitions and their arguments. Fourth, we show that beliefs concerning specific policy instruments such as cap and 
trade do not contribute to the formation of opposing coalitions; rather, there is quite a widespread consensus on these instruments. Finally, we discuss the implications of our findings to the empirical literature on climate change policymaking in the US and to the conceptualization of the belief system in the ACF theory. We will also address the limitations of our study, related to the use of media material in identifying coalitions.

\section{Theoretical Framework and Research Questions}

The Advocacy Coalition Framework posits that organizations group into coalitions based on shared beliefs. Some kinds of beliefs, however, are more critical than others in binding coalitions together. Jenkins-Smith et al. (2014, p. 185) describe a belief system as a hierarchical, "three-tiered structure". Deep core beliefs are fundamental ontological beliefs which may extend to multiple policy subsystems. Policy core beliefs, in turn, are specific to the policy subsystem. Normative policy core beliefs range from ideas about whose welfare counts the most to value priorities. Empirical policy core beliefs concern the causes and severity of a policy problem and its solutions (ibid. 191). Secondary beliefs deal with smaller subsets, described as "instrumental means for achieving the desired outcomes in the policy core beliefs" (Jenkins-Smith et al. 2014, p. 191). They include narrower beliefs, concerning, for example, issues in locales and budgets.

Empirical studies support the idea that the middle level of the hierarchical belief system, the policy core beliefs, is what plays the most crucial role in structuring interactions between organizations into coordination networks (Sabatier \& Weible 2005; Leifeld 2013; Ingold 2014). The hierarchy of beliefs implies that beliefs differ in their susceptibility to change (Jenkins-Smith et al. 2014): whereas deep core beliefs are very resistant to change, the policy core is held 
less rigidly, and secondary aspects are even more readily altered in light of new information. Policy actors are expected to be more willing to compromise in secondary aspects than to yield in policy core issues and to dismiss deep core debates (Sabatier \& Weible 2007; Jenkins-Smith et al. 2014).

Since the definition of policy core beliefs is wide, ACF scholars have measured coalitions with different types of beliefs. This has led to inconsistency and problems in theory accumulation about the role of different types of beliefs in policy making. For example, Sabatier and Weible (2005) measure coalitions using four policy core beliefs, ranging from the problem definition to specific policy instruments, in their survey on marine protected areas in California. Some studies, however, have shown that coalitions may be formed around specific policy preferences alone (e.g. Leifeld 2013). Yet others have independently measured the influence of normative policy core beliefs and specific policy instruments on coalition formation, finding that both do have an effect (Ingold 2011). Ingold did, however, use the term 'secondary beliefs' when referring to policy instruments in her study on Swiss climate policy. Overall, the creators of the ACF have recently assessed that theorizing the belief system remains "analytically underdeveloped and inconsistent in empirical research" (Jenkins-Smith et al. 2014, p. 196), and called for clarification, especially concerning the relationship between policy core and secondary beliefs.

The latest developments in the debate concerning the belief system in the ACF have focused on the relationship between the two top levels, deep core beliefs and policy core beliefs. Important advances in this respect have been made by Sotirov and Winkel (2016) and Jenkins-Smith et al. (2014), both broadening the conceptualization of the belief system in the ACF with insights from Cultural Theory 
(Douglas 1966; Douglas and Wildavsky 1982). Sotirov and Winkel suggest that shared or complementary core beliefs are key in enabling strategic cross-coalition alliances, while Jenkins-Smith et al. argue that understanding deep core beliefs in terms of Cultural Theory holds "considerable promise for enhancing the conceptual coherence and explanatory reach of belief systems within the ACF" (Jenkins-Smith et al. 2014, p. 485). At the same time, the equally important problem of the relationship between the two bottom levels, policy core beliefs and secondary aspects, has been identified in the literature (e.g. Jenkins-Smith et al. 2014, p. 196197) but we are not aware of systematic attempts at solving it.

In this paper, we focus on the role of policy core beliefs, such as those concerning the reality of anthropogenic climate change on the one hand, and beliefs concerning policy instruments such as cap and trade on the other as the "glue that holds a coalition together" (Sabatier 1998, p. 105). We investigate whether both types of beliefs play an equal role in coalition formation, or whether some of these beliefs do not have an effect and should thus be classified as secondary. Our empirical case is the climate change policy domain in the United States. Following earlier studies (Leifeld 2013; Lodge and Matus 2014), we use media material to investigate coalitions and their beliefs.

The climate policy domain has been highly conflictual for decades, which indicates that organizations' fundamental beliefs are against each other. Organizations involved include political parties, universities, government agencies, environmental organizations, and conservative Christian groups; climate change has become a highly salient issue that everyone seems to have something to say on. The case is thus likely to provide a wide range of beliefs and potential coalitions to analyze. 
Our main research questions are the following:

RQ1: Can we discern competing advocacy coalitions based on normative and empirical beliefs, such as those concerning the reality of anthropogenic climate change and prioritization of ecological over economic objectives?

RQ2: Can we discern competing advocacy coalitions based on specific policy preferences such as cap and trade?

\section{Method and Material}

Scholars have used a wide variety of research material, including interviews and surveys (Weible \& Sabatier 2005; Ingold 2011; Elgin \& Weible 2013; Author B, 2016), public policy documents (Jenkins-Smith et al. 1991; Heikkila et al. 2014) and, increasingly, media material (Leifeld 2013; Lodge and Matus 2014) to investigate the beliefs uniting advocacy coalitions. Our material is drawn from the mass media. Thus, our study has the same limitation as most ACF studies using text material such as policy documents or media material: we measure beliefs but not coordination of action among coalition members. The coalitions we identify, then, are best understood as discourse coalitions, i.e. groups of organizations that voice similar beliefs in the media debate. They may or may not work together to turn these beliefs into policy outside the media sphere, but our data does not allow for analyzing the extent to which such coordination takes place. Recent empirical evidence, though, supports the ACF assumption that belief homophily is a good predictor of inter-organizational collaboration (Matti \& Sandström 2011; 2013). Some other types of research material such as surveys are superior in the sense that they can measure both beliefs and coordination of action (e.g. Author B, 2016; Elgin 
\& Weible 2013), but they have other limitations, such as missing data due to low response rates.

We use the newly developed method of Discourse Network Analysis (DNA) (Leifeld 2010, 2013; Leifeld \& Haunss 2012; Fisher et al. 2012, 2013; Stoddart \& Tindall 2015). DNA combines social network and discourse analysis to create relational data by linking actors into networks, based on agreement or disagreement over policy beliefs. DNA, then, allows us to examine one of the most important features in policymaking, according to the ACF: 'the ideational structure of policy domains' (Leifeld \& Haunss 2012, p. 402).

Our research material consists of articles from three newspapers: The Wall Street Journal, USA Today and the New York Times. These are the three US newspapers with the largest circulation, and as such, can be expected to have significant impact on public opinion and policy elites. They also represent the political spectrum from (moderate) right to (moderate) left, enabling us to avoid ideological bias associated with any single news outlet. The WSJ represents conservative/right-leaning ideology, the NYT liberal/left-leaning ideology and USA Today centrist ideology (Gentzkow \& Shapiro 2010).

We examine the period 2007-08, for two reasons. First, it was a period during which media attention to global warming was just reaching its peak globally and in the US (Schmidt et al. 2013). Some drivers of the increased attention were Al Gore's movie An Inconvenient Truth (2006), the Stern Review on the economics of climate change (2006), IPCC's 4th assessment report (2007) and increased congressional activity around climate change legislation from 2007 onwards (Fisher et al. 2013). 
Second, and more importantly, this time period provides the best material for addressing our theoretical problem. Because we are interested in the differences between the kinds of policy beliefs that divide organizations into coalitions and those that do not, we pick a period during which some temporary elements of consensus are emerging in a field that has, before as well as after our sample period, been deeply divided (Knox-Hayes 2012; McCright, Xiao \& Dunlap 2014). In other words because the primary aim of this paper is to make a theoretical contribution to the ACF literature, rather than providing a comprehensive view of the climate change debate in the US, we have chosen our research material with this aim in mind. We will address the consequences of this choice below when discussing our results in relation to earlier findings about climate change politics in the US.

We searched Factiva using the search terms "global warming" and “climate change," and, after a manual check, chose only articles that dealt primarily with climate change. Of these articles, we selected a $20 \%$ random sample, resulting in total of 648 articles to be comprehensively coded. This dataset was then transferred in MS Word format into the Discourse Network Analyzer (DNA) software to code statements and organizations. DNA uses a statement as the unit of analysis. A statement is coded whenever an organization makes a claim about climate change that can be interpreted as a policy core belief, following the definition of ACF. Four attributes are coded for each statement:

First, the person making the statement is coded.

Second, the organization making the statement is coded.

Third, a belief category, is assigned to the statement.

Finally, a dummy variable indicating the organization's agreement or disagreement with the belief category is coded. 
We coded both direct quotes from organizations and statements that were paraphrased by the journalist. An example statement reads:

"Mr. Obama, the Democratic presidential candidate from Illinois, called for imposing a national cap for carbon emissions...' No business will be allowed to emit any greenhouse gases for free', Mr.Obama said in Portsmouth, N.H., 'Businesses don't own the sky, the public does, and if we want them to stop polluting it, we have to put a prize on all pollution."' October 9, 2007. The New York Times.

This statement is coded as follows: (1) Barack Obama, 2) Democratic Party, (3) the belief category "cap and trade is the legislative approach the US should take in addressing climate change", (4) and is in agreement with this belief category.

We formed the belief categories inductively, in an iterative process. We extracted a total of 1410 statements from 332 different organizations, which were coded into seventeen belief categories. For the purposes of our research questions, and in order to meaningfully analyze competing coalitions based on beliefs using network methods, we chose the six largest, most frequently appearing belief categories. Together, they represented $63 \%$ of all the statements. Table A1 in the Appendix lists all 17 belief categories. Of these six, three are more general normative and empirical policy core beliefs while the other three are beliefs concerning specific policy preferences. The three general beliefs are (1) the empirical belief concerning the reality of climate change and validity of climate science, expressed in the statement "the scientific claims that anthropogenic greenhouse gases contribute to climate change are valid"; (2) the normative belief that ecological objectives should be prioritized over economic ones, expressed in the statement "regulating GHG emissions to protect the environment is more important than protecting the economy"; and (3) the normative belief that governmental regulation is desirable, expressed in the statement "industry should be regulated in the US to decrease GHG emissions that contribute to climate change." The three beliefs concerning specific 
policy instruments we coded are (1) "cap and trade is the legislative approach the US should take in addressing climate change," (2) "higher auto efficiency standards are necessary in the US to reduce GHG emissions, which cause climate change" and (3) "increasing alternative energy production (wind, solar, hydro, geo, wave) is the approach the US should take in addressing climate change."

The final coding was then exported to Gephi software for social network analysis in order to create visual representations of the DNA data and to test for the existence of competing, belief-based advocacy coalitions with community detection methods. This was done by constructing co-occurrence networks of organizations via the belief categories, where a relationship is established between organizations if they both occur in the same belief category and both agree or both disagree with the belief. For example, a link between two organizations is established if they both state that climate science is valid, or if they both state that cap and trade is not a good policy instrument. A co-occurrence matrix is an undirected, weighted network, the edges of which reflect the strength of discursive association (Leifeld \& Haunss 2012). In the network, nodes represent the actors while edges represent shared agreement or shared disagreement on a belief category.

To detect the coalitions around shared policy beliefs, co-occurrence networks were analysed using the Louvain method, which measures how well a network decomposes into modular communities. The algorithm optimizes modularity, a value between -1 and 1 , which measures the density of links inside communities compared to links between communities If the value is larger than 0.4 , the differences between communities are usually considered meaningful (Blondel et al. 2008). In the case of weighted networks, such as the ones we analysed, modularity is defined as: 


$$
\mathrm{Q}=\frac{1}{2 \mathrm{~m}} \sum_{\mathrm{i}, \mathrm{j}}\left[\mathrm{A}_{\mathrm{ij}} \frac{\mathrm{k}_{\mathrm{i}} \mathrm{k}_{\mathrm{j}}}{2 \mathrm{~m}}\right] \delta\left(\mathrm{c}_{\mathrm{i}}, \mathrm{c}_{\mathrm{j}}\right),
$$

where $A_{i j}$ represents the weight of the edge between $i$ and $j, \mathrm{k}_{\mathrm{i}}=\sum_{\mathrm{j}} \mathrm{A}_{i j}$ is the sum of the weights of the edges attached to node $i, c_{i}$ is the community to which the node $i$ is assigned, the $\delta$ function $\delta(u, v)$ is 1 if $u=v$ and 0 otherwise and $\mathrm{m}=\frac{1}{2} \sum_{i j} \mathrm{~A}_{i j}$ (Blondel et al. 2008, 2-3).

\section{Results 1: Three Competing Coalitions Based on General Empirical and Normative Beliefs}

The answer to our first research question, "can we discern competing advocacy coalitions based on empirical and normative beliefs", is a clear yes: we find (1) a Pro-Economy and Counter-Science Coalition (henceforth the Economy Coalition for short), (2) an Ecology Coalition, and (3) a Science Coalition. Figure 1 shows that the discourse network is divided into three fairly distinct coalitions with many intra-coalition ties and fewer ties to other coalitions. The modularity value returned by the Louvain model, 0.474 , easily reaches the threshold of 0.4 , usually considered a criterion of meaningful coalitions (Blondel et al. 2008), confirming the visual observations that can be made from Figure 1. The node sizes represent the degree centrality of each organization, i.e. the number of ties that a node has.

A link between two organizations represents them taking the same position on an issue, i.e. both either agreeing or disagreeing on one of the following beliefs: (1) science validly shows that climate change is anthropogenic, (2), ecology is more important than economy and (3) governmental regulation of industry to curb climate change is desirable. 
FIGURE 1 Actor congruence network based on empirical and normative policy core beliefs

Table 1 below shows the positions of each coalition on these issues, demonstrating that they are highly consistent in expressing their beliefs. The Economy Coalition makes $97 \%$ of the statements denying the validity of climate science, $91 \%$ of the statements prioritizing the economy over the environment and $90 \%$ of the statements opposing industry regulation. The Ecology Coalition makes $98 \%$ of the statements in favor of industry regulation, $72 \%$ of the statements prioritizing the environment over the economy and $38 \%$ of the statements arguing for the validity of climate science. The Science Coalition makes $52 \%$ of the claims defending climate science and $16 \%$ of the claims prioritizing the environment over the economy.

TABLE 1 Share of statements by coalitions (\%)

The following three subsections look at the composition of each coalition and the content of their public statements to provide more in-depth evidence for the existence of coalitions. The Appendix presents the descriptive statistics showing the composition of each coalition by organization type.

\section{The Economy Coalition}

The most visible individual actor in the Economy Coalition is the Republican Party. Others include the Bush Administration, fossil fuel companies, groups from the conservative movement (e.g. Heartland Institute, Cato Institute), 
business lobbies (e.g. the Competitive Enterprise Institute, American Petroleum Institute) and trade associations from energy, manufacturing and agricultural sectors. The coalition is glued together by beliefs that relate to freedom of economy and its precedence over the environment. Members of this coalition often emphasize the uncertainty of climate science:

'For me, climate change is a human issue, not just an environmental one... The science of global warming is speculative. But there's nothing speculative about the damage a carbon dioxide capture program will do this country. I know the names of many of the thousands of people - American workers, their families - whose lives will be destroyed by what has become a deceitful and hysterical campaign, perpetrated by fearmongers in our society and by corporate executives' intent on their own profits or their competitive advantage. I can't stand by and watch.' (James Murray, CEO of Murray Energy, the Wall Street Journal, May 19, 2007)

However, only a few actors from the field of business attacked against climate science: instead, more often the conservative Christian groups, think tanks and the Republican Party saw IPCC-led climate science and related legislation as ideologically motivated and political rather than as a scientific project. Policy recommendations based on climate science were perceived to threaten the fundamental components of American culture, such as the nuclear family, religion, patriotism, and the freedom of the individual and economy.

Earlier research on the role of the climate change counter-movement (e.g. Farrell 2016) in undermining the need for climate policies would lead one to expect that the Economy Coalition would be dominant in the media debate. Somewhat contrary to this expectation, we find that while the economy coalition is, 
indeed the largest one of the three when measured in terms of the number of organizations belonging to it (44), the other two coalitions, the Ecology Coalition and the Science Coalition together easily outnumber it (64 organizations). Measured by the number of statements, the Economy Coalition is not dominant either: it makes 145 of the statements, while the other two coalitions combined make a total of 152. During the period analyzed here, then, the Economy coalition is strong but not clearly dominant in the mainstream media sphere.

\section{The Ecology Coalition}

Key organizations in the Ecology Coalition are international ones such as the IPCC and the EU and, on the national level, states. This finding marks a difference between our approach that uses media material and most studies using the $\mathrm{ACF}$, that tend to look at national actors only. In the media, and especially in debates that concern issues of global political and scientific relevance, international actors can, thus, be an important part of the coalition structure.

Environmental NGOs, the Democratic Party and some corporations are also part of this coalition. These organizations expressed the belief that the environment should be the number one priority in climate policy despite its possible economic costs and that protecting the environment does not have to exclude economic growth. In Kansas, the secretary of the Department of Health and Environment attempted to block the building of a coal-fired plant, a potentially big financial boost to the state, despite the opposition that came even from his own staff: "It would have been irresponsible to ignore emerging information about the contribution of carbon dioxide and other greenhouse gases to climate change and the potential harm for our environment and health if we do nothing." 
(Roderick L. Bremby, secretary of the Kansas Department of Health and Environment, the Wall Street Journal, March 19, 2008)

Indeed, states were visible in putting pressure on the federal government to reduce emissions by regulating industry. For example, 10 eastern states initiated the Regional Greenhouse Gas Initiative in 2007, the goal of which was significant reductions in power plant emissions, while on the West Coast, California was a proponent of industrial regulation.

A business coalition called BICEP (Business for Innovative Climate and Energy Policy), which includes some of the largest consumer product companies (such as Nike, Starbucks and Levi Strauss), called for stronger climate policies to create a green economy because they claim the economy will be hurt by the warming climate (USA Today, Nov. 20, 2008.) Thus, in the media sphere, there is a division within the corporate sector between those, (mainly fossil fuel) corporations that oppose any climate change legislation and those (mainly consumer product) corporations who see it as desirable. The extent to which the latter kind of corporations actually engage in concerted action beyond the media sphere with actors such as environmental organizations is, of course, a question that our media data does not permit us to answer.

\section{The Science Coalition}

The Science Coalition mainly consists of national and international universities. Members of the coalition believe that "Global warming is unequivocal and that human activity is the main driver, 'very likely' causing most of the rise in temperatures since 1950," as the IPCC (2007, p. 72) states. Many experts spoke of the significance of the IPCC $4^{\text {th }}$ assessment report: 
"Since 2001, there has been a torrent of new scientific evidence on the magnitude, human origins and growing impacts of the climatic changes that are under way...in overwhelming proportions, this evidence has been in the direction of showing faster change, more danger and greater confidence about the dominant role of fossil-fuel burning and tropical deforestation in causing the changes that are being observed." (John P. Holdren, president of the American Association for the Advancement of Science, the New York Times, Feb. 3, 2007)

These organizations perceive the policy problem of climate change as a scientific one, not taking stands on value priorities. Their statements often emphasized the negative environmental impacts: rising mean temperatures and sea levels, warming of lands and oceans, and extreme weather events. A few corporations and the UN also spoke for climate science.

\section{Results 2: No Competing Coalitions Based on Specific Policy \\ Instruments}

Our second research question asked whether we can discern competing coalitions built around specific policy instruments. Figure 2 shows a relatively unsegmented discourse network. This visual observation is confirmed by the modularity value returned by the Louvain method, 0.265 , which is well below the threshold of 0.4 and much lower than the figure produced by our analysis on normative policy core beliefs above (0.474). We tested several values for the resolution of the Louvain model, but the modularity values remained persistently low, and thus, all iterations failed to detect coalitions in the network. 
FIGURE 2 Actor congruence network based on specific policy

instruments.

A look at the number of organizations defending and opposing each of the three policy instruments and a qualitative analysis of the debate substantiates this argument. Table 2 shows that the majority of organizations agree on these instruments, despite the centrality of organizations that are usually opposed to ambitious climate policy, such as the Republican Party and industry organizations. Cap and trade is supported by $80 \%$, higher auto efficiency standards by $73 \%$ and increasing use of renewable energy by $89 \%$ of participants in the debate.

TABLE 2 The three most prevalent policy instruments in the debate and the share of organizations agreeing and disagreeing with them (\%)

Our qualitative analysis focuses mainly on cap and trade, the most debated issue in our material. The cap and trade debate was particularly prominent due to the Waxman-Markey bill, which sought to set up a mandatory cap-and-trade system for greenhouse gases. In the media, the bill was endorsed by most organizations, even corporations from energy, manufacturing and financial sectors, who stated it would further encourage firms to switch to alternative energies. During this period, many businesses saw some kind of regulation as inevitable, and thought of cap and trade as a lesser evil than carbon taxes. They thus attempted to influence the design of the cap and trade bill. A CEO of an energy company stated:

"We've got to find common ground among the stakeholders - consumers, industry, regulators, policy makers and environmental groups...they can't all 
be satisfied but there has to be some common ground so each of them can buy in.” (Jim Rogers of Duke Energy Corp., New York Times, March 7, 2007)

In January, 2007, ten companies from the electricity industry, including the coal mining industry, formed an informal coalition with leading environmental groups to push the federal government to reduce emissions by 10 to $30 \%$ in the next 15 years. Some of these business executives even testified before a Senate subcommittee on energy, recommending clean technology and federal caps as the best solutions to global warming. Some environmental organizations, in turn, denounced the fossil fuel companies' benevolence as calculating. Indeed, Duke Energy Corp. was at the time one of the biggest producers of carbon dioxide emissions in the US and was in the process of demanding permits for new coal plants (New York Times, March 7, 2007).

Many in the Republican Party as well argued for cap and trade and alternative energy:

"National security depends on energy security ... the profit motive [in cap and trade] will attract the transformational power of venture capital and unleash the market to move to clean alternative fuels and advanced energy technologies from the margins into the mainstream". (Senator John McCain, Republican Party, New York Times, April 23, 2007)

Like cap and trade, also alternative energies and setting auto efficiency standards found support across organizations. However, a minority of actors, such as the Bush Administration, individual members from the Republican and Democrat parties, business lobby and trade associations raised arguments opposing cap and 
trade, claiming that it would be economically disastrous and would result in the loss of jobs and of US national competitiveness.

\section{Discussion and Conclusions}

In this final section, we discuss the implications of our results to (1) the empirical literature on climate change policy in the US, and (2) the theory of the Advocacy Coalition Framework and the role of beliefs concerning policy preferences in it.

We found that disagreement over the general normative and empirical beliefs concerning the reality of anthropogenic climate change, the importance of ecology over economy and desirability of governmental regulation divide actors into three coalitions: the Economy Coalition, the Ecology Coalition and the Science Coalition. Specific policy instruments (cap and trade, auto efficiency standards and support for renewable energy) do not. Instead, the instruments find broad support across coalition lines and organization types.

These findings help in understanding the seemingly divergent results of earlier studies on US climate change politics, most finding increasing polarization but others finding elements of consensus. The overall story told in the literature is one of polarization and policy stagnation. The polarization is mainly over general policy core beliefs concerning the validity of climate science and the anthropogenic nature of climate change (McCright and Dunlap, 2011). Elements of consensus, however, were emerging at the high point of the media debate and legislative action on climate change in 2007-2008, both in the congress, as shown by Fisher et al. (2013) and the media, as shown here. The emerging consensus concerned mainly specific policy instruments, particularly cap and trade, while polarization remained over general policy core beliefs (cf. Fisher et al. 2012). As Pooley (2010) has shown, 
cap and trade legislation was indeed very close to passing in 2009 because it was moderate enough and able to win widespread support.

Since then, support for cap and trade has waned and polarization has increased. The climate change counter movement has regrouped and become stronger in opposing national climate legislation (Pooley 2010; Dunlap \& Jacques 2013; McCright, Xiao \& Dunlap 2014; Dunlap and McCright 2015). Studies have affirmed the influence of The Tea Party and its related groups, supported by the Koch brothers, who contribute to the increasing liberal-conservative divide by endorsing anti-environmental and anti-regulatory beliefs among political elites and the public (e.g. Mayer 2016; Skocpol \& Hertel-Fernandez 2016; Bohr 2016).

Overall then, our results obtained using media material are consistent with other studies looking at congressional hearings and public opinion polls, suggesting that the media, the congress and the polls are interlinked and combining the results of studies on all three gives a relatively accurate picture of the reality of US climate change politics and its changes over time.

The only significant divergence between our results and earlier applications of ACF in US climate change politics (e.g. Weible 2005; Heikkila et al. 2014) is that in our analysis based on media the environment and science coalitions appear as separate, while in studies using other material environmental groups and scientists often belong to the same advocacy coalition. It seems that in the media, there is a division of labor between scientific organizations advocating for climate science and environmentalists calling for policy action. The economy coalition, however, is a unified coalition: the same organizations are involved in countering both climate science and ecological/pro-regulatory beliefs. 
Our results must be read with the limitations of our data and method in mind. First, because our theoretical interest lies in the possibilities of building consensus across coalition lines, we chose data from a period where some consensus was developing in an otherwise contentious policy domain. Our empirical results, therefore, cover that period only, and should be complemented by further studies looking at the evolution of media discourse networks over time. Second, any study using media material is vulnerable to the possibility that there may be systematic bias in the kind of claims that journalists choose to report. Studies comparing positions taken by organizations in their documents or research interviews versus the ones that are reported in the media could be designed to investigate this type of bias. Third, there is a possibility that organizations strategically present positions in the media that are not consistent with their actions elsewhere; for a business firm and an environmental organization to take the same position on a particular policy instrument in the media debate does not mean that they consistently agree on environmental policy. Indeed, as our empirical analysis showed, environmental organizations often denounce pro-environment talk by businesses in the media as "greenwash". But we also found reports documenting coordinated action and joint statements by ENGO-business alliances. Fourth, we only measure beliefs, not coordination of action between coalition members. Research designs comparing media discourse networks with survey or interview data that includes information on collaboration would provide insight into how discourse networks reflect actual policy networks in terms of coordination and political influence. Such comparison would also help better grasp the dynamics of US climate policy making since not all organizations that are relevant in the policy subsystem necessarily appear in the media, for strategic reasons or as result of editorial decisions. 
Moreover, the key assumption of the ACF that shared beliefs are the most important factor influencing coalition formation has been questioned by some scholars. Resource dependency theory (RDT), for example, argues that organizational resources such as perceived influence are the strongest determinant of collaboration relationships (e.g. Stokman and Berveling 1998). However, testing RDT against ACF, Matti and Sandström $(2011 ; 2013)$ find that beliefs do matter more than resources, as predicted by the ACF. Thus, it seems reasonable to assume that the coalitions we find in this paper do also involve at least some degree of interorganizational collaboration.

Comparing our results on US climate politics with those of earlier studies on other policy domains, we propose the following clarification to the definition of the belief system in the ACF: Beliefs concerning the desirability and feasibility of specific policy instruments cannot be a priori classified as either policy core beliefs (beliefs that divide actors into coalitions) or secondary beliefs (beliefs that are less divisive). Rather, the role of beliefs concerning policy instruments in coalition formation varies between policy domains and periods of time. In the case studied here, policy instruments such as cap and trade find support across coalition lines and thus, are classified as secondary beliefs. In other policy domains, such as German pension policy studied by Leifeld (2013) and Swiss climate change policy studied by Ingold (2011), beliefs concerning policy instruments do divide organizations into coalitions and thus, ought to be classified as policy core beliefs. Our proposal is in line with early formulations of the ACF (e.g. Sabatier 1998), but as we showed above, the empirical literature is rather inconsistent in this respect, which has led to calls for conceptual clarification (Jenkins-Smith et al. 2014). 
An important task for future research, then, would be to try and specify the conditions under which beliefs concerning policy instruments are divisive, and the conditions under which they find support across coalition lines. Identifying these conditions would be helpful for understanding policy gridlocks and possibilities for policy change. A first step towards this direction is taken by Leifeld (2013, p. 193), who suggests that beliefs concerning policy instruments glue coalitions together especially in redistributive subsystems where the normal state of policy making is the dominance of one hegemonic coalition, in comparison to regulative ones where the normal state is often more competitive, including two to three competing coalitions. Comparative studies across policy domains and countries are needed to assess the generalizability of this suggestion, and to identify other possible conditions under which policy instruments divide policy actors or serve as devices for consensus building.

The ACF theorizes that policy change may occur through situations of 'negotiated agreement' when 'previously warring coalitions' need to stop a 'hurting stale mate' (Sabatier \& Weible 2007; Jenkins Smith et. al 2014). Our results suggest that the role of specific policy preferences, being more alterable than the more general beliefs, may be crucial during this type of policy process. The situation where consensus emerges over policy instruments while polarization remains over general policy core beliefs may, in fact, be relatively common. This is likely to apply especially to situations where there is a policy instrument on the table that gives something, so to speak, to both of the opposing coalitions, especially in highly conflictual, regulative subsystems. Cap and trade is an example of such an instrument. It gives environmentalists some form of legislation with potential to reduce emissions, and businesses are happy to see it done using a market mechanism, 
something that they tend to believe in more than, say, carbon taxes or outright government regulation of emissions. The specific solution speaks to the general policy core beliefs of both of the opposing coalitions and thus, has potential to act as a consensus-building device. This, we argue, is a possible explanation of the recent worldwide emergence of cap-and-trade systems instead of carbon taxes, even though the latter would likely be clearly more effective in reducing emissions (Avi-Yonah \& Uhlmann 2009; Wittneben 2009). Due to the single-case nature of our study and the limitations of our data, we offer these reflections not as a firm theoretical conclusion but rather, as a proposition to be examined in further studies. Work testing which kinds of policy instruments tend to gain support across coalition lines in different policy domains and polities could constitute a significant theoretical advance in the ACF. 


\section{References}

Avi-Yonah, R. S. \& Uhlmann, D. M. 2009. 'Combating Global Climate Change: Why a Carbon Tax is a Better Response to Global Warming than Cap and Trade', Stanford Environmental Law Journal, 28, 3.

Blondel, V. D, Guillaume, J-L., Lambiotte, R., Lefebvre, E. 2008. 'Fast Unfolding of Communities in Large Networks', Journal of Statistical Mechanics: Theory and Experiment, 10, P10008.

Bohr, J. 2016. 'The 'Climatism' Cartel: Why Climate Change Deniers Oppose Market-Based Mitigation Policy.' Environmental Politics, 25, 5, 812-830.

Boussalis, C. \& Coan, T. 2016. 'Text-Mining the Signals of Climate Change Doubt', Global Environmental Change, 36, 89-100.

Brulle, R. J., Carmichael J. \& Jenkins C. J. 2012. 'Shifting Public Opinion on Climate Change: an Empirical Assessment of Factors Influencing Concern over Climate Change in the U.S., 2002-2010', Climatic Change, 114, 169-188.

Douglas, M. 1966. Purity and Danger: An Analysis of the Concepts of Pollution and Taboo. New York: Routledge.

Douglas, M. \& Wildavsky, A. 1982. Risk and Culture. Berkeley: University of California Berkeley. 
Dunlap, R. \& Jacques P. 2013. 'Climate Change Denial Books and Conservative Think Tanks: Exploring the Connection', American Behavioral Scientist, 57, $699-731$.

Dunlap, R. \& McCright, A. 2015. 'Countering Climate Change: The Denial Countermovement', In Dunlap, R. \& Brulle, R. (eds), Climate Change and Society: Sociological Perspectives. Oxford: Oxford University Press.

Elgin, D. \& Weible C. 2013. 'Stakeholder Analysis of Colorado Climate and Energy Issues Using Policy Analytical Capacity and the Advocacy Coalition Framework'. Review of Policy Research, 30, 1, 114-133.

Farrell, J. 2015. 'Network Structure and Influence of the Climate Change CounterMovement.' Nature Climate Change, 6, 4, 370-374.

Farrell, J. 2016. 'Corporate Funding and Ideological Polarization about Climate Change', Proceedings of the National Academy of Sciences, 113, 1, 92-97.

Fisher, D., Waggle, J. \& Leifeld, P. 2012. 'Where does Political Polarization Come from? Locating Polarization within the US Climate Change Debate', American Behavioral Scientist, 57, 1, 70-92.

Fisher, D. R., Leifeld, P. \& Iwaki, Y. 2013. 'Mapping the Ideological Networks of American Climate Politics', Climatic Change, 116, 523-545. 
Gentzkow, M. \& Shapiro, JM. 2010. 'What Drives Media Slant? Evidence from U.S. Daily Newspapers'. Econometrica 78, 1, 35-71.

Greenberg, J., Knight, G. \& Westersund, E. 2011. 'Spinning Climate Change:

Corporate and NGO Public Relations Strategies in Canada and the United States', The International Communication Gazette, 73, 1-2, 65-82.

Heikkila T., Pierce J., Gallaher S., Kagan J., Crow D. \& Weible C. 2014. 'Understanding a Period of Policy Change: The Case of Hydraulic Fracturing Disclosure Policy in Colorado', Review of Policy Research, 31, 2, 65-87.

Hoffman, A. 2011. 'Talking Past Each Other? Cultural Framing of Skeptical and Convinced Logics in the Climate Change Debate', Organization \& Environment, $24,1,3-33$.

Ingold, K. 2011. 'Network Structures within Policy Processes: Coalitions, Power, and Brokerage in Swiss Climate Policy', Policy Studies Journal, 39, 3, 435-459.

Ingold, K. \& Fischer, M. 2014. 'Drivers of Collaboration to Mitigate Climate Change: An illustration of Swiss Climate Policy over 15 years', Global Environmental Change, 24, 1, 88-98.

IPCC. 2007. 'Fourth Assessment Report (AR4). Climate Change 2007: Synthesis Report'. 
Jenkins-Smith, H., St. Clair, G. \& Woods, B. 1991. 'Explaining Change in Policy Subsystems: Analysis of Coalition Stability and Defection over Time', American Journal of Political Science, 35, November, 851-872.

Jenkins-Smith, H. et al. 2014. 'The Advocacy Coalition Framework: Foundations, Evolution, and ongoing Research', in P. Sabatier, \& C. Weible (eds), Theories of the Policy Process. Boulder, CO: Westview Press.

Jenkins-Smith, H., Silva, C., Gupta, K. \& Ripberger, J. 2014. 'Belief System Continuity and Change in Policy Advocacy Coalitions: Using Cultural Theory to Specify Belief Systems, Coalitions, and Sources of Change', Policy Studies Journal, 42, 4, 484-508.

Jones, M. \& Jenkins-Smith H. 2009. 'Trans-subsystem Dynamics: Policy Topography, Mass Opinion and Policy Change', Policy Studies Journal, 37, 1, $37-58$.

Knox-Hayes J. 2012. 'Negotiating Climate Legislation: Policy Path Dependence and Coalition Stabilization', Regulation and Governance, 6, 545-567.

Leifeld, P. 2010. Discourse Network Analyzer (DNA) manual. Available online at: http://www.philipleifeld.de/discourse-network-analyzer-dna/manual/. 
Leifeld, P. 2013. 'Reconceptualizing Major Policy Change in the Advocacy Coalition Framework: A Discourse Network Analysis of German Pension Politics', Policy Studies Journal, 41, 1, 169-198.

Leifeld, P. \& Haunss, S. 2012. 'Political Discourse Networks and Conflict over Software Patents in Europe', European Journal of Political Research 51, 382409.

Leiserowitz, A., Maibach, E., Roser-Renouf, C., Feinberg, G., and Rosenthal, S. 2016. Politics and Global Warming, Spring 2016. Yale University and George Mason University, New Haven, CT: Yale Program on Climate Change Communication.

Lodge, M. and Matus, K., 2014. 'Science, Badgers, Politics: Advocacy Coalitions and Policy Change in Bovine Tuberculosis Policy in Britain', Policy Studies Journal, 42, 3, 367-390.

Matti, S. \& Sandström, A. 2011. 'The Rationale Determining Advocacy Coalitions: Examining Coordination Networks and Corresponding Beliefs', Policy Studies Journal, 39, 3, 385-410.

Matti, S., \& Sandström, A. 2013. 'The Defining Elements of Advocacy Coalitions: Continuing the Search for Explanations for Coordination and Coalition Structures', Review of Policy Research, 30, 2, 240-257. 
Mayer, J. 2016. Dark Money: The Hidden History of the Billionaires behind the Rise of the Radical Right, New York, Doubleday.

McCright, A. \& Dunlap, R. 2011. 'The Politicization of Climate Change and Polarization in the American Public's Views of Global Warming 2001-2010', Sociological Quarterly, 52, 155-194.

McCright, A. \& Dunlap, R. 2000. 'Challenging Global Warming as a Social Problem: an Analysis of the Conservative Movement's Counter-claims', Social Problems, 47, 4, 227-248.

McCright, A. \& Dunlap, R. 2003. 'Defeating Kyoto: The Conservative Movement's Impact on US Climate Policy', Social Problems, 50, 3, 348-373.

McCright, A., Xiao C., and Dunlap, R. 2014. 'Political Polarization on Support for Government Spending on Environmental Protection in the USA, 1974-2012,' Social Science Research, 48, 251-60.

Oreskes, N. \& Convay, E. M. 2010. Merchants of Doubt. London: Bloomsbury Press.

Pooley, E. 2010. The Climate War. True Believers, Power Brokers, and the Fight to Save the Earth. New York: Hyperion. 
Rabe, B. G. 2009. 'Second-Generation Climate Politics in the States: Proliferation, Diffusion, and Regionalization', in S. VanDeveer (eds), Changing Climates in North American Politics: Institutions, Policymaking, and Multilevel Governance. Cambridge: MIT Press.

Rabe, B. G. 2010. 'The Aversion to Direct Cost Imposition: Selecting Climate Policy Tools in the United States Governance. An International Journal of Policy, Administration, and Institutions, 23, 4, 583-608.

Sabatier, Paul A. 1998. 'The Advocacy Coalition Framework: Revisions and Relevance for Europe', Journal of European Public Policy, 5, 98-130.

Sabatier, P. \& Jenkins-Smith, H. 1999. 'The Advocacy Coalition Framework: An Assessment', in P. Sabatier (eds), Theories of the Policy Process. Boulder, CO: Westview Press, pp. 117-166.

Schmidt A., Ivanova A. \& Schäfer, M. 2013. 'Media Attention for Climate Change around the World: A Comparative Analysis of Newspaper Coverage in 27 Countries', Global Environmental Change, 23, 1233-1248.

Schäfer, M. \& Schlichting, I. 2014. 'Media Representations of Climate Change: A Meta-analysis of the Research Field', Environmental Communication, 8, 2, 142160. 
Skocpol, T. \& Hertel-Fernandez, A. 2016. 'The Koch Network and the Rightward Shift in U.S. Politics,' Presented at the Annual Meeting of the Midwest Political Science Association, Chicago, IL.

Sotirov, M. \& Winkel, G. 2016. 'A Cognitive Theory of Shifting Coalitions and Policy Change: Linking the Advocacy Coalition Framework and Cultural Theory', Policy Sciences, 49, 2, 125-154.

Stoddart, M. \& Tindall, D. 2015. 'Canadian News Media and the Cultural Dynamics of Multilevel Climate Governance', Environmental Politics, 24, 3, 401-422.

Stokman, F. N. \& Berveling, J. 1998. 'Dynamic Modeling of Policy Networks in Amsterdam', Journal of Theoretical Politics, 10, 4, 577-601.

Weible, C. M., Sabatier, P. A., Jenkins-Smith, H. C., Nohrstedt, D., Henry, A. D. \& deLeon, P. 2011. 'A Quarter Century of the Advocacy Coalition Framework: An Introduction to the Special Issue', Policy Studies Journal, 39, 3, 349-360.

Weible, M. \& Sabatier, P. 2005. 'Comparing Policy Networks: Marine Protected Areas in California', Policy Studies Journal, 33, 2, 181-202.

Weible, M. 2005. 'Beliefs and Perceived Influence in a Natural Resource Conflict: An Advocacy Coalition Approach to Policy Networks', Political Research Quarterly, 58, 3, 461-475. 
Wittneben, B. B. 2009. 'Exxon is Right: Let us Re-examine our Choice for a Capand-trade System over a Carbon Tax', Energy Policy, 37, 6, 2462-2464. 


\section{Appendix}

TABLE A.1. Belief Categories in the US Media Debate on Climate Policy During 2007-08.

\begin{tabular}{|c|c|c|c|}
\hline Issue category & $\begin{array}{l}\% \\
\text { Disagree }\end{array}$ & $\begin{array}{l}\% \\
\text { Agree }\end{array}$ & $\begin{array}{l}\% \text { of all } \\
\text { categories }\end{array}$ \\
\hline $\begin{array}{l}\text { Cap \& Trade is the legislative approach the US should take } \\
\text { in addressing climate change. }\end{array}$ & $20 \%$ & $80 \%$ & $23 \%$ \\
\hline $\begin{array}{l}\text { Higher auto efficiency standards are necessary in the US to } \\
\text { reduce GHG emissions that cause climate change. }\end{array}$ & $27 \%$ & $73 \%$ & $13 \%$ \\
\hline $\begin{array}{l}\text { The scientific claims that anthropogenic greenhouse gases } \\
\text { contribute to climate change is valid. }\end{array}$ & $42 \%$ & $58 \%$ & $9 \%$ \\
\hline $\begin{array}{l}\text { Regulating GHG emissions to protect the environment is } \\
\text { more important than protecting the economy. }\end{array}$ & $63 \%$ & $37 \%$ & $7 \%$ \\
\hline $\begin{array}{l}\text { Industry should be regulated in the US to decrease GHG } \\
\text { emissions that contribute to climate change. }\end{array}$ & $37 \%$ & $63 \%$ & $6 \%$ \\
\hline $\begin{array}{l}\text { Increasing alternative energy production (wind, solar, } \\
\text { hydro, geo, wave) is the approach the US should use in } \\
\text { addressing climate change. }\end{array}$ & $11 \%$ & $89 \%$ & $5 \%$ \\
\hline $\begin{array}{l}\text { States should be able to have stricter GHG emissions laws } \\
\text { than the federal government. }\end{array}$ & $25 \%$ & $75 \%$ & $5 \%$ \\
\hline $\begin{array}{l}\text { The US should not wait for other major emitters to decrease } \\
\text { GHG emissions before reducing its own. }\end{array}$ & $52 \%$ & $48 \%$ & $5 \%$ \\
\hline $\begin{array}{l}\text { Technological solutions like carbon capture and storage } \\
\text { (CCS) are an appropriate way to mitigate climate change }\end{array}$ & $9 \%$ & $91 \%$ & $4 \%$ \\
\hline $\begin{array}{l}\text { Increasing biofuel production is an approach the US should } \\
\text { take in addressing climate change. }\end{array}$ & $33 \%$ & $67 \%$ & $4 \%$ \\
\hline $\begin{array}{l}\text { Increasing nuclear power generation is the approach the US } \\
\text { should take in addressing climate change. }\end{array}$ & $14 \%$ & $86 \%$ & $3 \%$ \\
\hline $\begin{array}{l}\text { Climate change legislation is needed to address climate } \\
\text { change in the US. }\end{array}$ & $11 \%$ & $89 \%$ & $3 \%$ \\
\hline $\begin{array}{l}\text { A carbon tax is the legislative approach the US should take } \\
\text { in addressing climate change. }\end{array}$ & $25 \%$ & $75 \%$ & $3 \%$ \\
\hline $\begin{array}{l}\text { Voluntary emission reductions are useful in helping the US } \\
\text { reduce GHG emissions. }\end{array}$ & $24 \%$ & $76 \%$ & $3 \%$ \\
\hline $\begin{array}{l}\text { Higher efficiency standards are needed in all sectors of the } \\
\text { economy to reduce GHG emissions. }\end{array}$ & $0 \%$ & $100 \%$ & $2 \%$ \\
\hline $\begin{array}{l}\text { Increasing hybrid/electric car production is the approach the } \\
\text { US should take in addressing climate change. }\end{array}$ & $14 \%$ & $86 \%$ & $1 \%$ \\
\hline $\begin{array}{l}\text { Climate change has led to many severe weather events and } \\
\text { related phenomena. }\end{array}$ & $25 \%$ & $75 \%$ & $1 \%$ \\
\hline
\end{tabular}


The Endangered Species Act (ESA) should be used as a way to regulate GHGs and protect arctic species from the impacts of climate change

Grand Total
$55 \%$

$45 \% \quad 1 \%$

$28 \% \quad 72 \% \quad 100 \%$

TABLE A.2. Organizations in the Economy Coalition, share of statements by organization type $(N=145, \%)$

Republican Party

Foreign Government

Bush Administration

Business Lobby/Trade Associations

Energy Companies (fossil fuels)

National Government

Conservative Groups

Democratic Party

Academic

Other

Total

TABLE A.3. The Ecology Coalition, share of statements by actor type, $(N=86, \%)$

$\begin{array}{lc}\text { States } & 20 \\ \text { Foreign Government } & 15 \\ \text { ENGO's } & 14 \\ \text { Democratic Party } & 10 \\ \text { National Government } & 10 \\ \text { Business } & 7 \\ \text { Energy Companies (fossil fuels) } & 5\end{array}$


Academic/Research

Other

Total

TABLE A.4. The Climate Science Coalition, share of statements by actor type, $(N=66, \%)$

$\begin{array}{lr}\text { Academic/Research } & 68 \\ \text { United Nations } & 6 \\ \text { Business } & 6 \\ \text { ENGO's } & 4 \\ \text { Political Parties } & 4 \\ \text { Foreign Government } & 3 \\ \text { Other } & 9 \\ \text { Total } & 100\end{array}$

